\title{
INTER-CLAUSAL DEPENDENCY IN WESTERN TAMANG
}

\author{
Ambika Regmi
}

Western Tamang, a highly embedding dialect of Tamang, presents an array of inter-clausal dependency (both semantically and syntactically) ranging from most to least exemplified by verbal complements and chained clauses, respectively. In terms of such dependency, subordinate adverbial clauses stand in between verbal complements and chained clauses in Western Tamang. This is, indeed, a typologically interesting phenomenon, especially, in inter-clausal dependency in Bodic languages like Tamang.

Key words: dependency, verbal complements, subordinate, pragmatic, discourse context

\section{Background}

This paper analyzes the inter-clausal dependency in Western Tamang. By inter-clausal dependency, we simply mean the connections (both semantic and syntactic) between the clauses combined by different devices, basically, in the domains of subordinate adverbial clauses and coordinate chained clauses. Western Tamang is a dialect of Tamang, others being Eastern Tamang [taj], Eastern Gorkha Tamang [tge], Northwestern Tamang [tmk], Southwestern Tamang [tsf] (Eppele et al., 2012; Yonjan-Tamang, 2016). Western Tamang is exclusively spoken in Bagmati and Narayani Zones of Nepal. In Bagmati Zone, it is spoken in west Nuwakot, Rasuwa, Dhading districts, northeastern Sindhupalchok District, Bhote Namlan, Bhote Chaur, west bank of Trishuli River towards Budhi Gandaki River. In Narayani Zone, it is mainly spoken in northwestern Makwanpur District, Phakel, Chakhel, Kulekhani, Markhu, Tistung, Palung; northern Kathmandu, Jhor, Thoka, Gagal Phedi (Eppele et al., 2012). Typologically, Western Tamang is a complex tonal, consistently ergative, aspect prominent, highly embedding and extremely nominalizing dialect of Tamang

Nepalese Linguistics, vol. 34, 2019, pp. 36-42.
(Regmi and Regmi, 2018: 128). ${ }^{1} \quad$ Like Eastern Tamang (Lee, 2011; Mazaudon, 2003), Western Tamang makes use of verbal complements, subordinate adverbial clauses and coordinate/chained clauses for coding different levels of semantic/pragmatic dependencies in the multi-propositional discourse context. In this dialect, as expected typologically, verbal complements are most dependent to the matrix clauses for semantic/pragmatic effects whereas coordinate/chained clauses are least dependent to each other for such effects. In terms of interclausal dependency, subordinate adverbial clauses stand in between verbal complements and chained clauses.

This paper is organized into four sections. In section 1, we look at the inter-clausal dependencies in verbal complements in Western Tamang. Section 2 examines inter-clausal dependency in subordinate adverbial clauses. In section 3, we look at such dependency in coordinate/chained clauses in Western Tamang. Section 4 summarizes the findings of the chapter.

\section{Dependency in verbal complements}

In Western Tamang, verbal complements show the highest level of dependency semantically and syntactically. Semantically, the verbal complements function as subject or object arguments of other clauses. Such arguments functioning as the nominal arguments are tightly integrated with the main clause semantically and syntactically in Western Tamang as in (1).
(1) $t^{h}$ eje $b^{h}$ ya soba semji
$t^{h}$ e-je [b $b^{\text {hy }}$ so-ba] sem-ji
3SG-ERG marriage do-NMLZ want-PFV
'She wanted to get married.'

\footnotetext{
${ }^{1}$ The word order is in Western Tamang is generally rigid. However, clausal constituents may be permuted from their stipulated positions for contrastive topicalization, contrastive focusing, wh-questions and passive construction ( Regmi and Regmi, 2018).
} 
In example (1) two simple events coded by lexical verbs so 'do' and sem 'want' in two simple clauses have been merged semantically as a unitary complex event and syntactically integrated as a complex single clause. Basically, such integration results from some specific morpho-syntactic processes in Western Tamang. They are as follows:

a) The verbal complement is embedded in the main clause with the finite verb morphology.

b) It receives a single intonation contour with main clause.

c) Non-finite verbal morphology, i.e., nominal form of the verb marked by the nominalizer suffix $-b a$, is used in the complement clause.

d) The verbal complement as object of the finite verb is governed by the subject of the matrix clause.

e) The subject of the matrix clause marked by ergative case suffix $-j e$ and the subject of the complement clause are co-referential. The equi-NP in complement clause has been deleted.

\section{Dependency in subordinate adverbial clauses}

The dependent adverbial clauses are connected semantically and pragmatically with their main clauses in Western Tamang. In terms of distribution, there are two types of adverbial subordinate clauses: Pre-posed and post-posed. They display distinct dependency features. ${ }^{2}$

Western Tamang makes use of a number of grammaticalized connectives ('subordinators') to specify the situational context for the events or states described in the main clause. Besides, Western Tamang mostly employs pre-posed adverbial clauses. Inter-clausal dependency in clauses such as temporal, conditional, concessive, reason, purposive, etc., is briefly discussed as follows:

2 Givón (2001 Vol.II:343) notes that a post-posed adverbial clause displays a more semantic connection to its main clause. However, a pre-posed adverbial clause shows a more pragmatic coherence.

\subsection{Temporal adverbial clauses}

Western Tamang employs temporal adverbial clauses to specify both precedence and subsequence relations in the discourse context. In order to specify the precedence relation, the grammaticalized connective yonje 'before' is employed in the subordinate clause as in (2).

(2) yamburi $k^{h}$ aba yonje ya nuwakotti tiba
yamburi $\mathrm{k}$ a-ba yonje ya
Katmandu come-NMLZ before 1SG
nuwakot-ti ti-ji
Nuwakot-LOC live-PFV
'I lived in Nuwakot before I came to
Kathmandu.'

In example (2), the verb of the subordinate clause is in a nominal form of the verb. The subordinate clause has been placed before the main clause. Inter-clausal gap between the subordinate and the main clause is filled up by the subordinator yonje 'before'. Even the verb of the main clause may also be in non-finite form.

Western Tamang makes use of grammaticalized connective lipce 'after' to specify the subsequence relation of the adverbial clause to its main clause as in (3).

(3) calu dejim lipce yaje e:da yotla

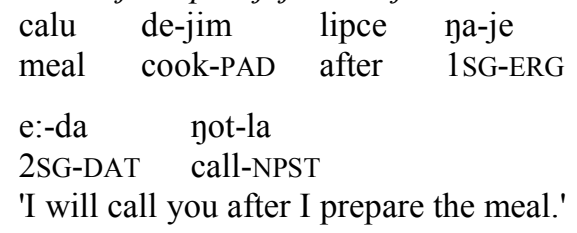

In example (3) the subordinate clause with nonfinite form of the verb (marked by the adverbial suffix -jim to indicate the following event) is linked with the main clause with finite verb morphology by the subordinator lipce. Moreover, the event coherence in (2) and (3) is coded by lexical verbs marked for different temporality, aspectuality and modality. It is to be noted here that the adverbial clauses in examples (2) and (3) present a more pragmatic coherence than semantic as they are both pre-posed clauses. The earlier event has been focused and following is topicalized in examples (2) whereas in example 
38 / Coding coherence in...

(3) following event is focused and earlier event is topicalized as per the discourse context.

\subsection{Conditional adverbial clauses}

There are two types of conditional adverbial clauses in a natural language: irrealis conditionals and counter-fact conditionals. However, Western Tamang has only irrealis conditionals. It makes use of the clause with the non-finite form of the verb marked by the suffix -sam in (4).
(4) a. nam taisəm ya $k^{h}$ aakam
nam tai-səm na $\mathrm{k}^{\mathrm{h}} \mathrm{a}$ a-kəm
rain fall-COND $1 \mathrm{SG}$ come NEG-can
'I will not come if it rains.'
b. nam atวisəm ya $k^{h} a m b a$

nam a-təi-səm na $\mathrm{k}^{\mathrm{h}}$ am-ba
rain NEG-fall-COND $1 \mathrm{SG}$ come-NMLZ
'I will come if it does not rain.'

In examples $4(a-b)$, both subordinate clauses are pre-posed for pragmatic effects as in examples (2) and (3). It is to be noted here that in Tamang, the nominalizer marker $-b a$ is also used to mark nonpast tense. Thus, the verb marked with -ba assumes the role of finite verb in the main clause.

\subsection{Reason adverbial clauses}

Western Tamang employs the grammaticalized connective talesam 'because' to combine the reason clause with the main clause as in (5).

a. yaje syorino ken caji talesam ya $k^{h}$ renji

ya-je syorino ken ca-ji

1SG-ERG early rice eat-PFV

talesəm ya $\mathrm{k}^{\mathrm{h}}$ ren-ji

because $1 \mathrm{SG}$ be.hungry-PFV

'I ate rice early because I was hungry.'

b. muna tapa talesom dimri ada

muna ta-pa talesəm dim-ri

night have-NMLZ because house-LOC

a-da

NEG-reach

'As the night fell, we did not reach home.'

In example (5a), the adverbial clause is postposed whereas in example $(5 \mathrm{~b})$, it is pre-posed.

\subsection{Concessive adverbial clauses}

In Western Tamang, the root of the verb is suffixed by the concessive adverbial marker -leino in order to reflect a contrast of some sort between the main and the subordinate clause as in (6).

a. ya prayna taleino sita muba

ya prayna ta-leino sita

1SG poor become-CONC honest

mu-ba

COP-NMLZ

'I am honest although I am poor.'

b. ajyaleino $t^{h}$ e ya sem tayba

$\begin{array}{lll}\text { a-jya-leino } & \mathrm{t}^{\mathrm{h}} \mathrm{e} \text { ya sem } \\ \text { NEG-good-CONC } & 3 \mathrm{SG} \text { 1SG like } \\ \text { tay-ba } \\ \text { do-NMLZ } \\ \text { 'I like her although she is not beautiful.' }\end{array}$

In example 6(a-b), both adverbial clauses are preposed to the main clauses. ${ }^{3}$

\subsection{Purpose adverbial clauses}

Western Tamang employs the non-finite form of the verb marked by the suffix -tibri in the purpose adverbial clauses as in (7).

(7) taya kamaitibri ya hyakko ge soba

tana kəmai-tibri ya hyakko

money earn-PURP 1SG lot of

ge so-ba

work do-NMLZ

'I work hard to earn money.'

\subsection{Location adverbial clauses}

Western Tamang employs the interrogative pronoun $k^{h}$ ana 'where' to indicate location in the subordinate clauses. Such clause is pre-posed as in (8).
(8) e: $k^{h}$ ana yiji ya ino hujuri yila
e: $\mathrm{k}^{\mathrm{h}}$ ana ji-ji ya ino hujuri yi-la
2SG where go-PFV 1SG also there go-NPST
'I will go where you go.'

\footnotetext{
${ }^{3}$ As in (4b) the verbs marked by the nominalizer -ba in (6a-b) may be assumed as being in non-past tense. Thus, such verbs may function as finite verbs in such clauses in Tamang.
} 


\subsection{Manner adverbial clauses}

The manner adverbial clauses are the non-finite clauses embedded in the matrix clause (Regmi and Regmi, 2018). In addition, such clauses employ rayle 'as same as' in the complex of clause as in (9).

(9) theje seryo syappa rayle tam payba

$\mathrm{t}^{\mathrm{h}} \mathrm{e}$-je serno syap-pa ray-le

3SG-ERG cold suffer-NMLZ same-MAN

tam pay-ba

matter speak-NPST

'He speaks as if he is suffering from common cold.'

\subsection{Participial adverbial clauses}

In Western Tamang, the participial adverbial clause like verbal complements is tightly integrated into the main clause (Regmi and Regmi, 2018). The subject of such adverbial clause is co-referent with the subject of the main clause (Referential coherence). Such adverbial clause tends to receive the rigid tense-aspectmodality vis-à-vis its main clause (Temporal coherence): simultaneity (imperfective aspect) and anteriority (perfect aspect). In terms of temporal coherence, there are two types of participial adverbial clauses: Simultaneous and sequential. The simultaneous participial adverbial clause in Western Tamang is formed by reduplicating the root of the verb being followed by the adverbial participial suffix- jim/-cim as in (10).

(10) a. naje brabra cacajim dimri niji naje bra-bra ca-ca-jim 1SG-ERG walk-PAD eat-eat-PAD

dim-ri $\quad$ ji-ji

house-ERG go-PFV

'While eating and walking, I went home.'

b. yaje brabrajim tam paypay ge soji ya-je bra-bra-jim tam 1SG-ERG walk-walk-PAD talk
pay-pan ge
so-ji
speak-speak work do-PFV
'While walking and talking, I worked.'

The simultaneous adverbial clauses as in (10a-b) are used to express the activity which is simultaneous with, or temporally overlapping with another activity expressed by the matrix predicate.

The sequential participial adverbial clause in Western Tamang is formed by simply suffixing the participial adverbial suffix -jim/-cim to the verb root as in (11).

(11) a. jaje ken cajim bojar niji

ja-je ken ca-jim bəjar ni-ji son-ERG rice eat-PAD market go-PFV 'After having eaten rice, the son went to market.'

b. tini neseri $k^{h} u$ dejim ken caji

tini nese-ri $\mathrm{k}^{\mathrm{h}} \mathrm{u} \quad$ de-jim today evening-LOC curry prepare-PAD

ken ca-ji

rice eat-PFV

'In the evening, after having prepared curry the rice was eaten.'

c. ja iskulti nijim dimri $k^{h}$ aji

ja iskul-ti ji-jim dim-ri

son school-LOC go-PAD house-LOC

$\mathrm{k}^{\mathrm{h}} \mathrm{a}-\mathrm{ji}$

come-PFV

'After having gone to school, the son returned home.'

The sequential adverbial clauses as in (11a-c) are used to code the event which is understood to have occurred prior to the event coded in the matrix predicate. Syntactically, the participial adverbial clauses exhibit less-finite verb morphology than the main clause but more finite than infinitival verbal complements.

Western Tamang may make use of nonspecialized sequential adverbial which presents a variety of other contextual meanings as well. One of them is to show the cause as in (12). 
40 / Coding coherence in...

(12) ge asyayjim $t^{h}$ e dimri dojim $k^{h}$ aji ge a-syay-jim $\mathrm{t}^{\mathrm{h}} \mathrm{e}$ dim-ri work NEG-find-PAD 3SG house-LOC

do-jim $\quad \mathrm{k}^{\mathrm{h}} \mathrm{a}-\mathrm{ji}$

back-PAD come-PFV

'After not having found work, he

returned home.'

The simultaneous constructions are used to express the activity which is simultaneous with, or temporally overlapping with another activity expressed by the matrix predicate as in (13).

(13) ya n $^{h}$ en ${ }^{h}$ ejim iskulti nijim

ya $\mathrm{n}^{\mathrm{h}} \mathrm{e}-\mathrm{j}^{\mathrm{h}} \mathrm{e}-\mathrm{jim}$
1SG laugh-laugh-PAD
yi-ji-m
go-PFV-FOC
'I went to school, laughing.'

The participial adverbial clauses, sequential and simultaneous, in Western Tamang are normally pre-posed. They may be post-posed as a discourse strategy such as afterthought or focus as in (14).

(14) ya iskulti nijim $n^{h}$ en ${ }^{h}$ ejim

na iskul-ti ni-ji-m

1SG school-LOC go-PFV-FOC

$\mathrm{n}^{\mathrm{h}} \mathrm{e}-\mathrm{n}^{\mathrm{h}} \mathrm{e}-\mathrm{jim}$

laugh-laugh-PAD

'I went to school, laughing.'

As mentioned earlier, both simultaneous and sequential adverbial clauses receive tense-aspect from the verbs in the matrix clauses as in (15).

(15) a. calu cajim ya $r^{h}$ iri yiji

calu ca-jim na $\mathrm{r}^{\mathrm{h}} \mathrm{i}-\mathrm{ri} \quad$ ji-ji meal eat-PAD $1 \mathrm{SG}$ jungle-LOC go-PFV 'After having eaten meal, I went to the jungle.'

b. ki thuyt unjim ya $r^{h}$ iri yiji

ki $\mathrm{t}^{\mathrm{h}}$ un- $\mathrm{t}^{\mathrm{h}} \mathrm{un}-\mathrm{jim}$ ya $\mathrm{r}^{\mathrm{h}} \mathrm{i}-\mathrm{ri}$

water drink-drink-PAD 1SG jungle-LOC

ni-ji

go-PFV

'While drinking water I went to the jungle.'
It is to be noted that in Western Tamang, most of the adverbial clauses are pre-posed to the main clause. Thus, they are pragmatically more coherent but semantically less integrated into the semantic structure of the main clause. In terms of inter-clausal dependency, adverbial clauses enjoy the intermediary position in Western Tamang. Givón (2001 Vol.II:347) notes that a pre-posed adverbial clause serves as a coherence bridge. It maintains a cataphoric semantic links to subsequent main clause and anaphoric pragmatic links to the preceding discourse.

\section{Conjoined ('chained') clauses}

Conjoined ('coordinate/chained') clauses are semantically least dependent in terms of interclause dependency. Western Tamang exhibits different types of conjoined clauses in terms of degree and type of their connectivity. To code inter-clausal connectivity, Western Tamang employs basically four types of conjunctions: continuative, contrastive, disjunctive and excluding. Thus, there are four types of conjoined clauses. They are briefly discussed as follows:

\subsection{Continuative conjoined clauses}

The independent clauses in Western Tamang may be conjoined by using the continuative conjunction tiy 'and' as in (16).

(16) yala ja tiy jame jyaba mula

$$
\begin{aligned}
& \text { ya-la ja tin jame jya-ba } \\
& \text { lSG-GEN son and daughter good-NMLZ } \\
& \text { mu-la } \\
& \text { COP-NPST } \\
& \text { 'My son and daughter are good.' }
\end{aligned}
$$

In example (16) the two clauses are conjoined by the conjunction tiy 'and' in Western Tamang. This conjunction codes the greater cataphoric continuity than the contrastive conjunction.

In Western Tamang, two clauses may be conjoined without using any conjunction. Such clauses may be simply juxtaposed as in (17).

(17) ja jame iskul jiji

$$
\begin{aligned}
& \text { ja jame iskul yi-ji } \\
& \text { son daughter school go-PFV } \\
& \text { 'The son and daughter went to school.' }
\end{aligned}
$$




\subsection{Contrastive conjoined clauses}

In Western Tamang, contrastive clauses are conjoined by using the contrastive conjunction debe 'but' as in (18).

a. ja $k^{h}$ aji debe jame $a k^{h} a$

$$
\begin{array}{llll}
\text { ja } & \mathrm{k}^{\mathrm{h}} \mathrm{a}-\mathrm{ji} & \text { debe } & \text { jame } \\
\text { son come-PFV } & \text { but daughter } \\
\mathrm{a}-\mathrm{k}^{\mathrm{h}} \mathrm{a} & & & \\
\text { NEG-come.PFV } & &
\end{array}
$$

'The son returned but the daughter did not.'

b. ja sijoy debe jame $c^{h}$ oba

ja sijon debe jame

son overweight but daughter

$\mathrm{c}^{\mathrm{h}} \mathrm{o}-\mathrm{ba}$

slim-NMLZ

'The son is overweight but the daughter is slim.'

c. jame ge soji debe ja ase

$\begin{array}{lllll}\text { jame } & \text { ge } & \text { so-ji } & \text { debe } & \text { ja } \\ \text { daughter } & \text { work } & \text { do-PFV } & \text { but } & \text { son } \\ \text { a-se } & & & & \\ \text { NEG-do.PFV } & & & \end{array}$

'The daughter worked but the son did not work.'

Such clauses (18a-c) are used to code referential as well as thematic discontinuity in Western Tamang.

\subsection{Disjunctive conjoined clauses}

Western Tamang does not have any native coordinator for disjunction. Because of long and constant contact with Nepali, Western Tamang also has borrowed the Nepali coordinator $k i$ 'or' for disjunction as in (19).

$$
\begin{aligned}
& \text { a. ja ki jame } k^{h} \text { aji } \\
& \text { ja ki jame k } \mathrm{k}^{\mathrm{h}} \mathrm{a}-\mathrm{ji} \\
& \text { son or daughter come-PFV } \\
& \text { 'Son or daughter came.' } \\
& \text { b. e: tiba ki ya tise } \\
& \text { e: ti-ba ki ya ti-se } \\
& \text { 2SG sit-NMLZ or 1SG sit-NMLZ } \\
& \text { 'Do you sit or I sit?' }
\end{aligned}
$$

\subsection{Excluding conjoined clauses}

Western Tamang does not have native coordinators for exclusion. It has borrowed from Nepali which is indicated by bahek 'except' as in (20).

$$
\begin{aligned}
& \text { a. } t^{h} \text { e ken bahek toin aca } \\
& \mathrm{t}^{\mathrm{h}} \mathrm{e} \text { ken bahek təinə a-ca } \\
& \text { 3SG milk except other NEG-eat.NPST } \\
& \text { 'He eats nothing except rice.' } \\
& \text { b. jaje ne bahek toinə aca } \\
& \text { ja-je je bahek təinə } \\
& \text { son-ERG milk except other } \\
& \text { a-ca } \\
& \text { NEG-eat.NPST } \\
& \text { 'The son does not take anything } \\
& \text { except milk.' }
\end{aligned}
$$

\section{Summary}

In this paper, we examined inter-clausal dependency in Western Tamang. It is a highly embedding language. The verbal complements represent the highest level of inter-clausal dependency semantically and syntactically in Western Tamang. The verbal complements have non-finite verb morphology as the coding devices. Dependent adverbial clauses are connected semantically and pragmatically with their main clauses in Western Tamang. Typologically, this dialect contains temporal adverbial, conditional adverbial, reason adverbial, concessive adverbial, purpose adverbial, location adverbial, manner adverbial and participial adverbial clauses. Such clauses exhibit semantic as well as syntactic connections when they are combined with the main clauses by employing different devices. In Western Tamang, the participial adverbial clause like verbal complements is tightly integrated into the main clause. Conjoined clauses are semantically least dependent in terms of interclause dependency. To code inter-clausal connectivity, Western Tamang employs basically four types of conjunctions: continuative, contrastive, disjunctive and excluding.

Abbreviations

1SG first person singular 
42 / Coding coherence in...

$\begin{array}{ll}\text { 3SG } & \text { third person singular } \\ \text { CAUS } & \text { causative } \\ \text { CONC } & \text { concessive } \\ \text { COND } & \text { conditional } \\ \text { COP } & \text { copula } \\ \text { DAT } & \text { dative } \\ \text { ERG } & \text { ergative } \\ \text { LOC } & \text { locative } \\ \text { MAN } & \text { manner } \\ \text { NEG } & \text { negative } \\ \text { NMLZ } & \text { nominalizer } \\ \text { NPST } & \text { non-past } \\ \text { PAD } & \text { participial adverbial } \\ \text { PFV } & \text { perfective } \\ \text { PURP } & \text { purposive }\end{array}$

References

Eppele, John W., M. Paul Lewis, Dan Raj Regmi and Yogendra P. Yadava. eds. 2012.
Ethnologue: Languages of Nepal. Kathmandu: Linguistic Survey of Nepal (LinSuN).

Givón, T. 2001. Syntax: An Introduction, Vol. I. Amsterdam: John Benjamins.

Lee, Sung-Woo. 2011. Eastern Tamang Grammar Sketch. MA dissertation presented to the Faculty of the Graduate Institute of Applied Linguistics, USA.

Mazaudon, Martine. 2003. "Tamang." In Graham Thurgood and Randy J. LaPolla (eds.), The Sino-Tibetan Languages. 291-314.London \& New York: Routledge.

Regmi, Dan Raj and Ambika Regmi. 2018. A Grammar of Western Tamang. München: LINCOM EUROPA

Yonjan-Tamang, Amrit. 2016. Adharbhut Tamang Vyakarana (Basic Tamang grammar). Lalitpur: NFDIN. 